\title{
PEMBELAJARAN BERPARADIGMA AL-QUR'AN UNTUK MENGATASI KESULITAN SISWA MADRASAH DALAM MEMPELAJARI MATEMATIKA
}

\author{
Abdussakir \\ Dosen pada program studi PGMI dan saintek UIN Malang
}

\begin{abstract}
Abstrak
We have known, mathematic is considered the difficult lesson by several students. The student mathematic achievement is very lack of satisfactory and very less, moreover madrasah's student. This article wants to offer the newest way to up grade the student's mathematic achievement. The mathematic learning should be performed by a heart, not only by a brain. This is a scientist concept at Koran who can use "fikir" and "dzikir", a heart and a brain, "bayani", "burhani" and "irfani" method in mathematic learning. In other word, the mathematic learning should be involved the intellectual questions (IQ), spiritual questions (SQ), and emotional questions (EQ).
\end{abstract}

Keyword: Paradigm, Matematic, al-Quran

\section{A. Pendahuluan: Hakikat Matematika}

Secara bahasa (lughawi), kata "matematika" berasal dari bahasa Yunani yaitu "mathema" atau mungkin juga "mathematikos" yang artinya "hal-hal yang dipelajari". Bagi orang Yunani, matematika tidak hanya meliputi pengetahuan mengenai angka dan ruang, tetapi juga mengenai musik dan ilmu falak (astronomi). Nasoetion (1980:12) menyatakan bahwa matematika berasal dari bahasa Yunani "mathein" atau "manthenein" yang artinya "mempelajari". Orang Belanda, menyebut matematika dengan wiskunde, yang artinya ilmu pasti. Sedangkan orang Arab, menyebut matematika dengan 'ilmu al hisab, artinya ilmu berhitung.

Secara istilah, sampai saat ini belum ada definisi yang tepat mengenai matematika. Para ahli filsafat dan ahli matematika telah mencoba membuat definisi matematika, tetapi sampai sekarang belum ada yang menyatakan bahwa jawabannya adalah yang terakhir. Belum ada definisi yang disepakati untuk menjelaskan matematika itu apa.

Matematika merupakan abstraksi dari dunia nyata. Karena matematika merupakan abstraksi dari dunia nyata, maka objek matematika bersifat abstrak, tetapi dapat dipahami maknanya. Untuk menyatakan hasil abstraksi, digunakan bahasa simbol. Untuk menyatakan bilangan "dua" digunakan simbol "2". Penggunaan bahasa simbol mempunyai dua keuntungan yaitu (a) sederhana dan universal, dan (b) mempunyai makna yang luas.

Matematika menganut pola pikir atau penalaran deduktif. Penalaran deduktif adalah pola berpikir yang didasarkan pada kebenaran-kebenaran yang secara umum sudah terbukti benar. Kebenaran yang diperoleh dari beberapa 
contoh khusus yang kemudian digeneralisasi, masih dikatakan bersifat induktif dan belum diterima kebenarannya dalam matematika. Kebenaran induktif perlu dibuktikan dengan penalaran yang ketat dan logis. Ahli matematika juga memperhatikan ilham, dugaan, pengalaman, daya cipta, rasa, dan fenomena dalam mengembangkan matematika. Kesimpulan dari pengembangan itu akan diterima setelah ditetapkan atau dibuktikan melalui penalaran logis.

Uraian di atas masih bersifat umum dan lebih banyak mengutip pendapat-pendapat ahli matematika Barat. Mungkin pembaca masih kesulitan dan bingung untuk memahami apa matematika sebenarnya. Dalam hal ini, penulis mempunyai pendapat yang agak berbeda mengenai matematika. Penulis berharap, uraian ini akan mempermudah pemahaman pembaca mengenai matematika.

Manusia sebenarnya hidup dalam dua dunia, yaitu dunia nyata dan dunia ghaib. Alam syahadah dan alam ghaibiyah. Dunia fisik dan dunia metafisik. Dunia empirik dan dunia nonempirik. Natural dan supranatural. Dunia yang nyata, syahadah, fisik, empirik, atau natural adalah dunia yang dapat kita lihat ini, bumi dan isinya. Dunia yang ghaib, ghaibiyah, metafisik, nonempirik, atau supranatural adalah dunia yang hanya ada di pikiran atau hati kita. Matematika hakikatnya tidak berada di dunia nyata dan tidak pula di dunia gaib. Dunia matematika berada di antara dua dunia itu. Kalau penulis gambarkan seperti pada Gambar 1 berikut ini.

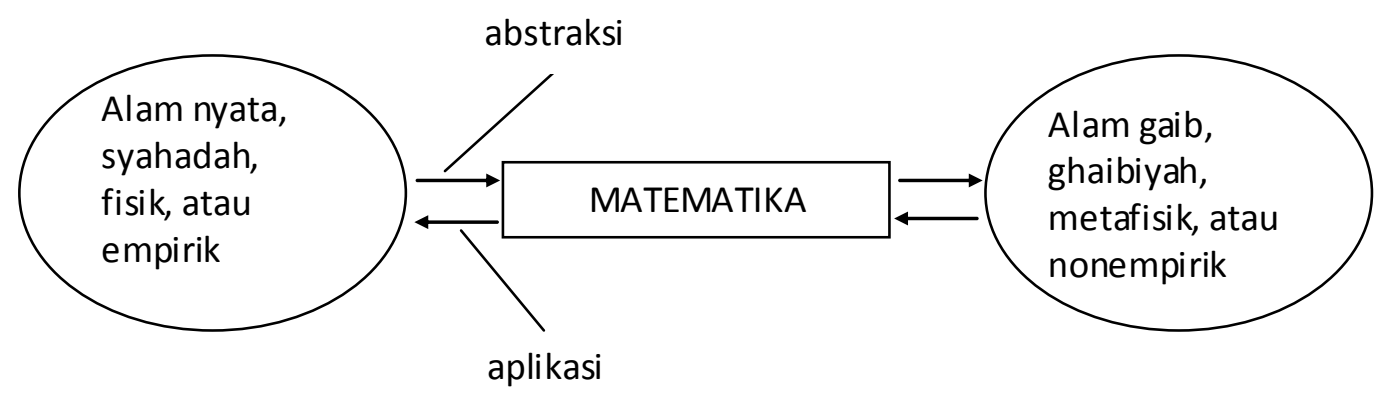

Gambar 1 Posisi Matemática 
Jika masalah dalam dunia nyata dibawa ke dalam dunia matematika maka terjadi proses yang disebut abstraksi. Dalam bahasa yang lain, terjadi pematematikaan horizontal. Masalah dunia nyata yang sudah diubah dari bahasa sehari-hari menjadi bahasa matematika (bahasa simbol) kemudian diselesaikan dalam dunia matematika. Proses ini disebut pematematikaan vertikal (Soedjadi, 2001:3). Menterjemahkan bahasa matematika ke dalam dunia nyata disebut aplikasi. Sedangkan hubungan dunia matematika dengan dunia ghaib, penulis tidak dapat menyebutkan namanya. Apakah juga abstraksi dan aplikasi.

Jadi, matematika itu tidak nyata dan juga tidak gaib. Ada di tengahtengah sifat itu. Setengah nyata dan setengah gaib. Abstrak tapi tidak benarbenar abstrak. Itulah hakikat keberadaan matematika menurut penulis. Pendapat penulis ini akan memberikan suatu cara belajar matematika yang mungkin berbeda dengan pendapat ahli matematika dan ahli pendidikan matematika pada umumnya. Belajar matematika memerlukan alat atau metode yang mampu menangkap sifat setengah nyata dan setengah gaib yang dimiliki matematika.

\section{B. Belajar Matematika}

Materi matematika itu sungguh tersusun rapi, ada urutan-urutannya mulai yang rendah sampai ke yang tinggi atau mulai yang tinggi baru ke yang rendah. Tepatnya, matematika itu bersifat hirarkis. Implikasi dari sifat hirarkis ini adalah pemahaman pada suatu konsep akan mempengaruhi pemahaman pada konsep berikutnya yang berkaitan. Seseorang yang mempelajari suatu materi B dan belum memahami materi A yang mendasari materi B, maka akan sulit bahkan tidak mungkin untuk memahami materi B (Hudojo, 1979:93). Hirarki yang dimulai dari konsep rendah (eksklusif) ke konsep yang lebih tinggi (inklusif) diprakarsai oleh Robert Gagne.

Berbeda dengan Gagne, David P Ausubel menyatakan hirarki yang berbeda. Hirarki yang diajukan Ausubel dimulai dari konsep yang inklusif menuju konsep yang eksklusif yang disebut subsumer. Melalui prinsip differensiasi progresif (progressive differentiation), Ausubel menyatakan bahwa konsep yang paling inklusif dan general hendaknya disampaikan pertama kali, dan selanjutnya secara terus-menerus dijabarkan ke dalam konsep-konsep yang detil dan khusus (Bell, 1978:134). Meskipun berbeda, kedua ahli tersebut samasama mengakui bahwa matematika bersifat hirarkis.

Jika dalam berwudhu adalah istilah tertib, urutannya benar, maka dalam belajar matematika juga dapat dikatakan harus tertib. Kalau tidak tertib, maka hasilnya akan berupa hafalan, bukan pemahaman. Hafalan mempunyai arti bahwa ilmu yang ada di otak akan menjadi satuan-satuan yang terisolasi, yang saling asing, dan tidak mempunyai saling keterkaitan dan saling keterhubungan. Hafalan terjadi karena pengetahuan baru tidak dibangun berdasarkan pengetahuan sebelumnya yang telah ada di otak atau mental siswa (Dahar, 1988:134).

Pemahaman dikatakan terjadijika pengetahun yang ada dalam otak tidak tersimpan sebagai satuan yang terisolasi, tetapi menjadi satuan-satuan yang 
terkoneksi satu dengan yang lain. Pemahaman terjadi karena pengetahuan baru dibangun berdasarkan pengetahuan yang telah ada di otak siswa sehingga terbentuk hubungan dan saling keterkaitan antara materi. Pengetahuan yang tersimpan dalam otak yang kaya dengan saling keterkaitan antar satuan-satuan pengetahuan membentuk struktur mental yang oleh Piaget disebut dengan skema (scheme) (Hudojo, 1979:82).

Menurut Jean Piaget, pengembangan skema melalui dua proses, yaitu assimilasi dan akomodasi. Assimilasi adalah proses masuknya atau menyatunya informasi baru ke dalam skema tanpa mengubah struktur skema yang telah ada. Akomodasi adalah proses masuknya informasi baru ke dalam skema, yang didahului dengan pengaturan kembali atau modifikasi informasi sebelumnya untuk mengakomodasi informasi baru atau bahkan terjadi pembentukan skema yang benar-benar baru (Hudojo, 1979:83).

Matematika memang bersifat abstrak, yang berarti bahwa objek-objek matematika diperoleh melalui abstraksi dari fakta-fakta atau fenomena dunia nyata. Karena objek matematika merupakan hasil abstraksi dunia nyata, maka matematika dapat ditelusuri kembali berdasarkan proses abstraksinya. Hal inilah yang mendasari bagaimana cara mempelajari matematika.

Belajar matematika perlu dilakukan secara bertahap menuju level abstraksi. Dengan demikian matematika perlu dipelajari melalui tahapan nyata (konkret), setengah nyata (semi konkret), dan abstrak. Penyajian matematika secara konkret dapat berupa masalah yang berkaitan dengan kehidupan nyata (realistik/kontekstual). Bahasa yang digunakan adalah bahasa sehari-hari yang dekat dengan kehidupan. Masalah yang disajikan perlu diselesaikan untuk menemukan suatu konsep atau prinsip. Jadi aktivitas matematika adalah aktivitas penemuan (discovery) melalui pemecahan masalah (problem solving). Sehingga dikatakan bahwa inti kegiatan belajar matematika adalah pemecahan masalah.

Masalah yang diajukan dalam belajar matematika adalah masalah realistik (berkaitan dengan kehidupan nyata) dan relevan (menggambarkan kegunaan matematika dan sesuai tahap berpikir). Masalah yang diajukan bukan masalah yang hanya dapat diselesaikan dengan satu cara, tetapi dapat diselesaikan dengan banyak cara, metode, dan pendekatan serta yang memungkinkan diperoleh solusi yang beragam. Masalah yang dapat diselesaikan dengan banyak cara, metode, dan pendekatan serta yang memungkinkan diperoleh solusi yang beragam disebut dengan masalah open-ended, masalah divergen, atau masalah berakhir terbuka.

Masalah realistik tidak selalu berupa masalah yang berkaitan dengan kehidupan dunia nyata. Masalah realistik dapat juga berupa masalah yang hanya dapat direalkan dalam pikiran siswa. Masalah realistik adalah masalah yang kadang sangat komplek dan sulit dihadirkan di dalam kelas. Untuk mengatasi hal ini, kadang diperlukan suatu media yang konkret dan dapat menggambarkan fenomena yang ada dalam masalah tersebut. Media ini disebut model dunia nyata (media semikonkret) yang dapat berupa gambar. Dengan 
demikian, dari konteks yang konkret pembelajaran matematika memasuki konteks yang semi konkret.

Pada tahap berikutnya digunakan bahasa matematika (bahasa simbol) untuk menyerderhanakan permasalahan. Penggunaan bahasa simbol merupakan tanda bahwa pembelajaran sudah berada pada tahap abstrak. Pemecahan masalah selanjutnya dilakukan dalam lingkup matematika dengan penalaran logis dan ketat. Proses abstraksi dari tahap konkret, semikonkret, dan abstrak oleh Jerome Bruner juga disebut tahap enactive, iconic, dan symbolic (Dahar,1988:124). Urutan tahap-tahap tersebut tidak selalu dari konkret, semi konkret, dan abstrak. Penggerakan tahap-tahap dapat dimulai dari mana saja sesuai kebutuhan.

Kesimpulannya, belajar matematika perlu memperhatikan urutan materi. Perlu memperhatikan syarat-syarat atau materi prasyarat untuk mempelajari suatu materi. Materi matematika harus saling terkait, artinya materi berikutnya hendaknya dibangun dari materi sebelumnya. Pemahaman akan terjadi jika materi matematika tersimpan dalam otak sebagai satuan-satuan yang berhubungan, tidak sekedar sebagai satuan-satuan yang terpisah. Untuk memudahkan memahami suatu materi dalam matematika, maka materi tersebut hendaknya diwujudkan dalam bentuk yang konkret (disajikan dalam bahasa dunia nyata), atau diilustrasikan dalam bentuk semi konkret (gambar) sebelum disajikan dalam bahasa simbol yang bersifat abstrak.

\section{Paradigma Al-Qur'an dalam Belajar Matematika}

Dalam kehidupan, manusia pada hakikatnya tidak sekedar berhadapan dengan objek-objek nampak (syahadah) tetapi juga bersinggungan dengan objekobjek tidak nampak (ghaibiyah). Manusia selalu berada dalam lingkup yang natural dan yang supranatural. Objek-objek yang natural mudah dipahami karena dapat diamati dengan indera tetapi objek-objek yang supranatural sulit dipahami karena berkaitan dengan keyakinan.

Sudah dijelaskan sebelumnya bahwa matematika berada di antara dunia syahadah (empirik) dan ghaibiyah (nonempirik) Untuk memahami objek yang nyata diperlukan pendekatan rasionalis, empiris, dan logis (bayani dan burhani). Sedangkan untuk memahami objek yang gaib diperlukan pendekatan intuitif, imajinatif, dan metafisis (irfani). Kekuatan utama dalam matematika justru terletak pada imajinasi atau intuisi yang kemudian diterima setelah dibuktikan secara logis atau deduktif. Dengan demikian, maka untuk mempelajari matematika perlu penggabungan ketiga pendekatan tersebut, yaitu bayani, burhani, dan 'irfani.

Pendekatan bayani artinya pemerolehan pengetahuan yang didasarkan pada teks-teks suci. Dalam perkembangan selanjutnya, teks suci mungkin dapat diartikan sumber-sumber bacaan yang telah diakui kebenarannya sebagai sumber ilmu. Rasio biasanya hanya sebagai penyangga dari kemapanan otoritas teks suci. Pendekatan burhani artinya pemerolehan pengetahuan yang dilakukan dengan menyandarkan diri pada kekuatan rasio dan menggunakan instrumen logika. Pendekatan 'irfani adalah pemerolehan pengetahuan dari pengalaman 
langsung atas realitas pengalaman keberagamaan. 'Irfani dapat juga diartikan sebagai pengungkapan atas pengetahuan yang diperoleh melalui penyinaran hakikat oleh Allah kepada hamba-Nya setelah adanya olah nurani. Dengan kesucian hati, Allah akan melimpahkan pengetahuan langsung pada hamba-Nya (Majalah INOVASI, 2005:16-17). Paradigma berpikir yang menggabungkan ketiga pendekatan tersebut, penulis sebut paradigma Al-Qur'an.

Ilmuwan dalam pandangan Al-Qur'an adalah sosok yang secara bersamaan mengembangkan potensi dzikir dan fikir untuk menghasilkan amal sholeh, yang dalam Al-Qur'an disebut Ulul Albab. Potensi dzikir berperan menghadapi objek yang suprarasional, dan mampu mempertajam kemampuan intuitif, emosional, dan spiritual. Potensi fikir berperan menghadapi objek yang rasional. Dzikir mewakili aktivitas pada aspek ghaibiyah dan fikir mewakili aktivitas pada aspek syahadah. Ulul albab tidak hanya mempelajari yang aqliyah atau kauniyah saja (alam semesta) melalui pendekatan burhani, tetapi juga yang naqliyah atau tanziliyah (wahyu) sebagai sumber ilmu melalui pendekatan bayani. Untuk selanjutnya, paradigma Al-Qur'an dalam tulisan ini diganti dengan istilah yang lebih spesifik, yaitu paradigma ulul albab.

Paradigma ulul albab ini dapat digunakan dalam belajar matematika. Kemampuan intelektual semata tidak cukup untuk belajar matematika, tetapi perlu didukung secara bersamaan dengan kemampuan emosional dan spiritual. Pola pikir deduktif dan logis dalam matematika sangat bergantung pada kemampuan intuitif dan imajinatif. Hal ini dilakukan dengan paradigma ulul $a l b a b$, yang mengembangkan pendekatan rasionalis, empiris, dan logis (bayani dan burhani) sekaligus pendekatan intuitif, imajinatif, dan metafisis (irfani).

Matematika memang untuk dipahami, tetapi pemahaman sangat berkaitan dengan ingatan atau hafalan. Memahami matematika berarti mampu mengaitkan objek matematika dengan objek matematika yang dipelajari sebelumnya. Jika objek yang telah dipelajari sebelumnya telah hilang/lupa, lalu apa yang akan dikaitkan. Inilah yang sering menjadi penyakit dalam belajar matematika, penyakit lupa. Padahal pengetahuan matematika hanya dapat dibangun dengan pondasi materi matematika sebelumnya.

Dalam mempelajari matematika dikenal objek-objek dalam belajar matematika. Objek yang dipelajari dalam matematika itu dibedakan menjadi 4, yaitu fakta (fact), ketrampilan (skill), konsep, dan prinsip (Bell, 1978:108).

Fakta adalah sebarang kesepakatan dalam matematika, misalnya simbolsimbol matematika. " 2 " adalah fakta yang digunakan sebagai simbol untuk kata "dua". "+" adalah fakta yang digunakan sebagai simbol untuk operasi penjumlahan. "sin" adalah fakta yang digunakan sebagai simbol untuk suatu jenis fungsi dalam trigonometri.

Keterampilan (skill) adalah prosedur-prosedur atau operasi-operasi yang siswa atau matematisi diharapkan dapat menggunakannya dengan cepat dan akurat. Skill ditandai dengan sejumlah aturan atau perintah, atau ditandai oleh rangkaian prosedur yang terurut yang biasa disebut algoritma. Pengetahuan mengenai fakta dan prosedur oleh Hiebert dan Lefevre (dalam Hiebert, 1986;6) 
disebut pengetahuan prosedural. Kemampuan untuk melakukan rumus-rumus atau prosedur-prosedur tanpa mengetahui mengapa rumus itu dapat berfungsi oleh Skemp (1987:166) disebut pemahaman instrumental.

Konsep adalah ide abstrak yang memungkinkan seseorang untuk mengklasifikasi suatu objek atau kejadian dan kemudian menentukan apakah objek atau kejadian itu merupakan contoh dan bukan contoh dari ide abstrak tersebut. Konsep dipelajari melalui definisi atau pengamatan (Bell, 1978:108-109).

Pengetahuan mengenai apa sesuatu itu oleh Dahar (1988:49) disebut pengetahuan deklaratif. Saling keterkaitan antara konsep oleh Van de Walle disebut pengetahuan konseptual. Menurut Hiebert dan Lefevre (dalam Hiebert, 1986:3-4), pengetahuan konseptual adalah saling keterkaitan antara satuan-satuan informasi, yang dapat berupa fakta dan konsep. Van de Walle (1990:6) menyebutkan bahwa jika terjadi saling keterkaitan antara fakta, antara konsep, dan antara fakta dan konsep maka akan terbentuk pemahaman relasional. Skemp (1987:166) mengartikan pemahaman relasional sebagai kemampuan untuk menghasilkan aturan atau prosedur khusus dari saling keterkaitan konsep matematika yang lebih umum. Menurut Skemp (1987:166), kemampuan untuk menghubungkan simbol-simbol dan notasi-notasi matematika (fakta) dengan konsep matematika dan kemampuan mengkombinasikan fakta dan konsep ke dalam jaringan penalaran logis adalah pemahaman formal atau pemahaman logis.

Prinsip adalah rangkaian konsep disertai dengan keterkaitan antar konsep-konsep itu. Prinsip biasanya berupa teorema atau dalil-dalil (Bell, 1978:109).

Hal yang perlu diperhatikan bahwa fakta mempunyai peranan penting. Meskipun demikian, untuk mengenal fakta perlu didahului dengan pengenalan konsepp. Fakta tidak lain adalah bahasa symbol untuk mewakili suatu konsep tertentu. Jika fakta dikenal sebelum konsep, maka makna dibalik fakta akan hilang. Fakta tidak akan mewakili apa-apa dan akan menjadi sia-sia.

Selanjutnya akan dijelaskan bagaimana bentuk konkret belajar matematika sesuai paradigma ulul albab tersebut. Untuk tujuan ini, maka penulis akan memberikan ilustrasi berikut. Penulis yakin bahwa pembaca sudah pernah melakukan rekreasi. Mungkin saat di sekolah dasar (SD) dulu. Bukankah sampai sekarang pembaca masih mengingat pengalaman rekreasi tersebut. Bukankah seandainya penulis meminta pembaca untuk menceritakan kembali rekreasi itu, pembaca dapat menceritakannya kembali secara runtut mulai awal hingga akhir. Kira-kira mengapa bisa demikian? Mengapa pembaca masih ingat, padahal waktu itu tidak berniat dan tidak berusaha mengingat atau menghafalnya?

Ilustrasi kedua, misal kepada pembaca diberikan 35 jilid novel KUNG FU BOY atau DETEKTIF CONAN. Tiap jilid memuat 100 halaman, sehingga total semuanya 3500 halaman. Kira-kira berapa lama pembaca akan selesai membaca novel itu? Penulis yakin bahwa pembaca akan sanggup membaca dalam waktu semalam atau dua malam. Seandainya masih bersambung, mungkin pembaca masih akan mencari sambungannya dan akan merasa penasaran jika tidak dapat membaca sambungannya. Seandainya pembaca diminta menceritakan kembali 
novel tersebut, tentunya pembaca dapat menceritakannya dengan urutan yang baik. Pembaca akan mengingat tokoh-tokoh dan alurnya dengan cukup detail. Mengapa bisa demikian? Padahal waktu membaca, pembaca tidak berniat menghafal sama sekali isi novel tersebut.

Ilustrasi ketiga, misalnya penulis memberikan kepada pembaca satu buku matematika, yang hanya memuat 35 halaman. Mungkin dalam waktu semalam, pembaca tidak akan dapat menyelesaikan tugas membaca atau mempelajari buku tersebut. Seandainya, keesokan harinya pembaca diminta menceritakan isi buku matematika itu, jangankan isinya, mungkin judul buku dan pengarangnya, pembaca tidak akan ingat. Mengapa bisa lupa dan tidak ingat sama sekali? Bukankah saat membaca novel pembaca tidak berpikir, tetapi justru saat membaca buku matematika pembaca berpikir?

Jawaban yang jelas dari semua ilustasi yang telah dikemukakan di atas adalah adanya aktivitas menikmati. Adanya perasaan senang dan santai saat melakukan rekreasi dan membaca novel, tetapi perasaan senang dan santai hilang saat membaca buku pelajaran. Pembaca sungguh melakukan aktivitas menikmati saat rekreasi maupun saat membaca novel. Tidak ada aktivitas berpikir saat itu. Emosional atau hati yang mengadakan aktivitas menikmati, bukan intelektual atau otak yang menikmati. Inilah fakta bahwa kemampuan intelektual (pikir) "kalah" atau sangat dipengaruhi pada kemampuan emosional dan spiritual (dzikir). Saat rekreasi atau membaca novel, kemampuan emosional dan spiritual (dzikir) yang sangat dominan sehingga muncul aktivitas menikmati, tetapi saat belajar matematika kadang hanya kemampuan intelektual (pikir) yang digunakan.

Teori barat (misalnya Amerika) menganjurkan bahwa pembelajaran matematika perlu dilakukan dalam konteks yang menyenangkan melalui aktivitas bermain (learning by doing). Ternyata, akibatnya kadang siswa hanya ingat bermainnya saja. Teori ini sebenarnya mengakui bahwa emosi sangat berpengaruh dalam belajar matematika, dan emosi sangat dipengaruhi spiritual. Hal inilah yang tidak dipahami orang barat. Bagaimana mungkin proses berpikir (intelektual) akan maksimal jika perasaan (emosional) sedang kacau? Apakah perasaan dapat dibohongi dengan permainan yang menyenangkan.

Kemampuan berpikir jernih (intelektual) atau kemampuan berkonsentrasi sangat dipengaruhi oleh perasaan (emosional), dan emosional sangat dipengaruhi oleh pemahaman keagamaan (spiritual). Kalau hati tenang, lapang, selapang lautan luas, maka pikiran akan mampu bekerja maksimal. Tenangnya hati, sesuai tuntunan Al-Qur'an, akan tercapai melalui aktivitas berdzikir. Sebagaimana firman Allah dalam Al-Qur'an surat Ar-Ra'd ayat 28.

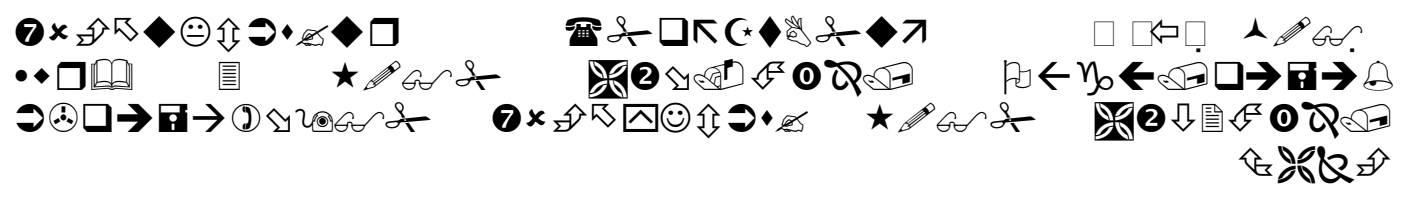


Artinya : (yaitu) orang-orang yang beriman dan hati mereka manjadi tenteram dengan mengingat Allah. Ingatlah, hanya dengan mengingati Allah-lah (dzikrullah) hati menjadi tenteram."

Sesuai ayat tersebut, jelas bahwa hanya dzikirlah (spiritual) yang dapat menenangkan perasaan (emosianal). Inilah yang dapat dilakukan ulul albab.

\section{Belajar dengan Hati, Mungkinkah?}

Pertanyaan yang muncul selanjutnya adalah apakah mungkin dalam belajar kita hanya menggunakan kemampuan emosional dan spiritual, seperti saat membaca novel? Atau dengan pertanyaan berbeda, apakah mungkin orang menjadi kaya tanpa bekerja? Jawaban terhadap pertanyaan tersebut adalah sangat mungkin. Tidak ada yang tidak mungkin atas kuasa Allah. Hanya orangorang yang berjiwa sekuler yang akan menjawab tidak mungkin. Untuk belajar matematika tanpa intelektual sangatlah sulit, tetapi bukan berarti tidak bisa.

Apakah artinya hati bisa melakukan aktivitas berpikir atau bernalar? Seorang sufi bernama Jalaluddin Rumi (Agustian, 2005:xxxix) menyatakan bahwa hati mempunyai kemampuan 70 kali lebih kuat daripada dua alat indera penglihatan untuk melihat kebenaran. Sedangkan $\mathrm{KH}$ Bahauddin Mudary (2001:85) menyatakan bahwa hati bisa menembus (ruang dan waktu) bahkan menembus lembar-lembar buku sedangkan indera tidak bisa. Selain itu, AlQur'an surat Al-A'raf ayat 179 yang mengisyaratkan bahwa hati dapat memahami (faqiha) dan dalam surat Al-Hajj ayat 46 mengisyaratkan bahwa hati dapat bernalar ('aqala).

Penulis mempunyai penjelasan tersendiri yang mungkin tidak ilmiah, dan mungkin tidak akan diakui oleh ahli pendidikan manapun. Marilah lihat kembali alam kita. Alam ini memuat alam syahadah dan alam ghaibiyah. Ternyata pada diri kita juga ada dua alam, alam syahadah yaitu jasmani dan alam ghaibiyah yaitu ruhani. Kita punya potensi jasmani dan ruhani. Penulis gambarkan seperti pada Gambar 2 berikut.

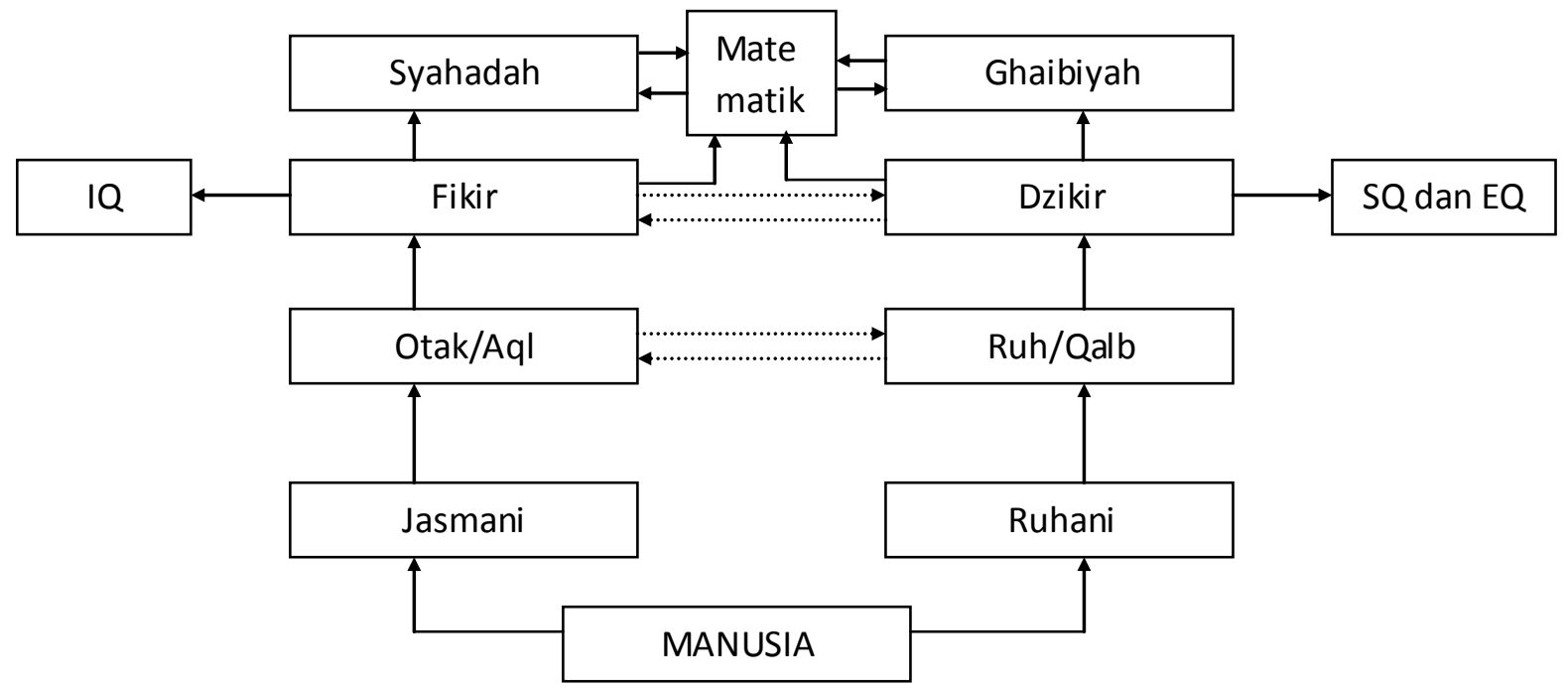




\section{Gambar 2 Potensi Jasmani dan Ruhani untuk Mempelajari Matematika}

Jasmani itu dikontrol oleh otak atau aql. Meskipun demikian, aql dapat tidak bermakna otak. Otak dalam bahasa Arab adalah dimagh, bukan aql. Penulis dalam hal ini menyebut otak dengan aql, karena aql berarti sebagai bagian dari manusia yang memiliki kemampuan untuk memperoleh atau menyimpan pengetahuan. Otak melakukan aktivitas berpikir yang ditandai dengan kecerdasan intelektual atau IQ. Otak menangkap objek-objek yang besifat empirik yakni alam syahadah.

Ruhani dikontrol oleh ruh atau qalb atau hati. Hati melakukan aktivitas berdzikir yang ditandai dengan kecerdasan spritual dan emosional atau SQ dan EQ. Hati menangkap objek-objek yang besifat nonempirik yakni alam ghaibiyah. Hati (qalb) dalam tulisan ini tidak bermakna hati secara jasmani. Hati tidak bermakna segumpal daging yang berada dalam dada. Hati (qalb) adalah sesuatu yang halus, lembut, tidak kasat mata, tidak berupa, dan tidak dapat diraba. Imam Ghazali (2005:26) menyebutnya sebagai lathifah yang bersifat rabbani ruhani. Qalb inilah yang merupakan hakikat manusia atau jati dirinya.

Matematika seperti telah dijelaskan sebelumnya, ada di antara alam syahadah dan alam ghaibiyah. Dengan demikian, matematika perlu dipelajari dengan kedua potensi kita, jasmani dan ruhani, aql dan qalb secara bersamaan. Qalb saja memang dapat mempelajari matematika, tetapi kadang tidak dapat memberikan penjelasan yang logis dan rasional. Qalb dapat menjawab $3+4=7$, tetapi kadang tidak dapat menjawab mengapa bisa 7. Aql saja dapat mempelajari matematika, tetapi kadang terlalu lama dalam berpikir dan tidak dapat menangkap hakikat.

Mempelajari matematika melalui jalur ruhani, penulis sebut dengan metode kasyaf. Kasyaf (keterbukaan selubung penutup) akan diperoleh melalui olah ruhani atau riyadhah yaitu penyucian hati (tazkiyatun nafs). Orang yang telah mencapai kasyaf disebut sebagai orang yang mukasyafah. Ilmu yang diperoleh melalui kasyaf disebut ilmu ladunni atau ilmu hudhuri. Mempelajari matematika melalui jalur jasmani, penulis sebut metode kasab. Kasab artinya berusaha keras secara jasmani, misalnya belajar giat atau istilahnya melalui ikhtiyar jasmaniyah. Ilmu yang diperoleh melalui kasab disebut ilmu kasbi.

Belajar matematika perlu melibatkan potensi intelektual, emosional, dan spiritual secara bersamaan. Perlu penggunaan aql dan qalb secara bersama, melalui jalur jasmani (kasab) dan juga jalur ruhani (kasyaf). Aspek pengembangan kemampuan berpikir (kognitif), sikap (afektif), dan prilaku (psikomotor) dalam belajar matematika dapat tercapai dengan baik dengan paradigma ulul albab. Potensi dzikir untuk mengembangkan aspek afektif dan fikir untuk mengembangkan aspek kognitif agar menghasilkan amal sholeh (psikomotor). Belajar matematika yang abstrak, yang memerlukan kemampuan pikir dan imajinasi dapat dilakukan dengan paradigma ulul albab yang menggunakan pendekatan rasionalis, empiris, dan logis (bayani dan burhani) sekaligus pendekatan intuitif, imajinatif, dan metafisis (irfani). 


\section{E. Dzikir dan Tazkiyah untuk Melejitkan Potensi Hati}

Peningkatan potensi qalb dalam mempelajari matematika dapat dilakukan dengan dzikrullah. Dzikir itu tidak hanya sekedar membaca kalimat thayyibah. Mengaji, mendirikan shalat, beramal shaleh, bahkan mempelajari alam ini demi membesarkan nama Allah juga termasuk dzikir. Dzikirullah bisa dilakukan bil lisan, bil hal, dan bil qalb sendiri. Mengerjakan amalan-amalan sunnah, mendirikan shalat-shalat sunnah disamping shalat wajib, terutama shalat malam, dapat melejitkan potensi qalb dengan cepat. Melakukan amalan sunnah secara kontinu (dawam), akan meningkatkan potensi ruhani dan kecerdasan ruhani. Allah berfirman dalam hadits qudsi riwayat Thabrani dari Abu Umamah yang artinya.

"Hamba-Ku senantiasa mendekatkan dirinya kepada-Ku dengan mengerjakan amal-amal sunnah, sehingga Aku mencintainya. Kalau Aku sudah cinta kepadanya, Akulah yang menjadi pendengarannya yang dengan itu dia mendengarkan, Aku menjadi lidahnya yang dengan itu dia berkata, Aku menjadi kalbunya yang dengan itu dia berpikir. Kemudian apabila dia berdoa kepada-Ku, Aku penuhi, apabila dia minta kepada-Ku, Aku beri, dan apabila dia minta tolong kepada-Ku, Aku tolong. Dan ibadah yang lebih Kucintai yang dilakukan hamba-Ku adalah ibadah yang dilakukan dengan ikhlas semata-mata karena Aku."

Dalam redaksi yang lain diriwayatkan oleh Bukhari sebagai berikut.

"Hamba yang senantiasa bertaqarrub kepada-Ku dengan ibadah-ibadah sunnah sehingga Aku mencintainya. Apabila Aku mencintainya, Aku adalah pendengaran yang dengannya ia mendengar. Aku adalah penglihatan yang dengannya ia melihat. Aku adalah tangan yang dengannya ia menampar. Aku adalah kaki yang dengannya ia berjalan. Jika ia memohon kepada-Ku, niscaya Aku kabulkan. Jika ia meminta perlindungan-Ku, niscaya Aku melindunginya."

Bisa dibayangkan, bagaimana jika pengetahuan Allah, setetes saja diberikan kepada kita. Maka selubung yang ada pada realitas ini akan tersingkap dan kita akan menemui makna hakiki. Tidak heran jika kemudian ada "manusiamanusia suci" yang mengetahui hal-hal gaib, mengetahui masa lalu dan mengetahui masa depan. Padahal itu hanya sedikit dari karunia Allah, setetes embun dibandingkan dengan banyaknya air di lautan luas.

Ilmu Allah, tanda-tanda kebesaran Allah, semuanya telah terhampar di depan kita, ayat-ayat kauniyah dan ayat-ayat tanziliyah telah berada di depan kita. Selanjutnya tinggal penyucian hati kita, agar ilmu dan hikmah bisa kita raih. Penyucian hati menjadi syarat dalam pemerolehan ilmu dan hikmah. Sebagaimana firman Allah dalam Al-Qur'an surat Al-Baqarah ayat 151. 


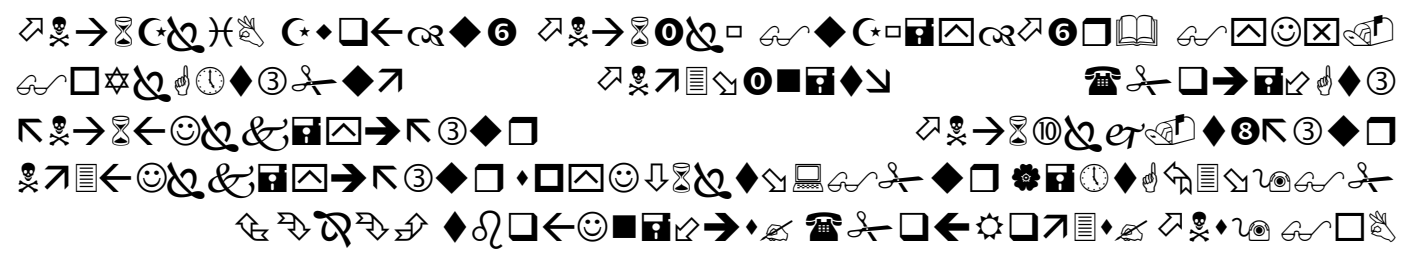

Artinya: Sebagaimana (Kami telah menyempurnakan nikmat Kami kepadamu) Kami telah mengutus kepadamu Rasul diantara kamu yang membacakan ayat-ayat Kami kepada kamu dan mensucikan kamu dan mengajarkan kepadamu Al Kitab dan Al-Hikmah, serta mengajarkan kepada kamu apa yang belum kamu ketahui.

Dalam Al-Qur'an surat Ali Imran ayat 164.

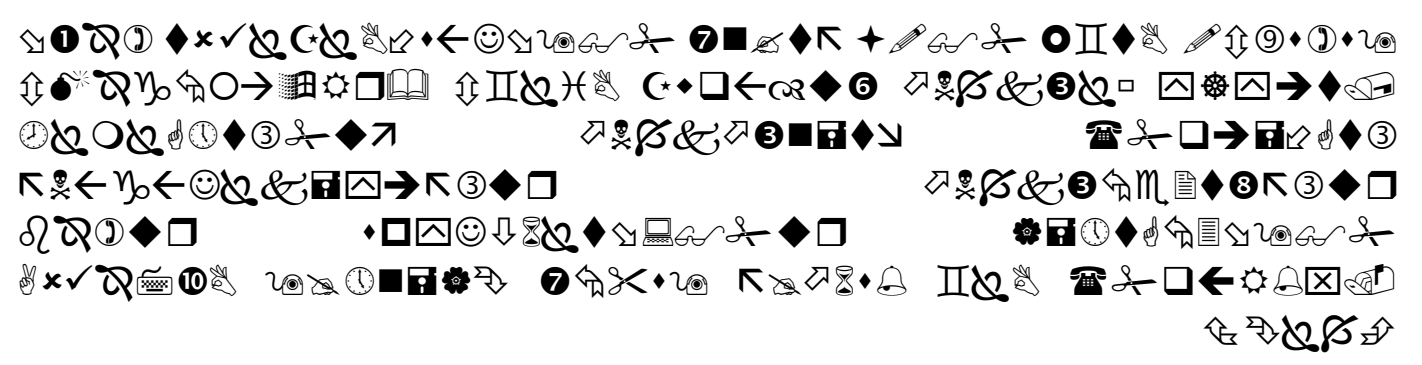

Artinya: Sungguh Allah telah memberi karunia kepada orang-orang yang beriman ketika Allah mengutus diantara mereka seorang rasul dari golongan mereka sendiri, yang membacakan kepada mereka ayat-ayat Allah, membersihkan (jiwa) mereka, dan mengajarkan kepada mereka Al Kitab dan Al Hikmah. Dan sesungguhnya sebelum (kedatangan Nabi) itu, mereka adalah benar-benar dalam kesesatan yang nyata.

Dalam Al-Qur'an surat Al-Jumu'ah ayat 2.

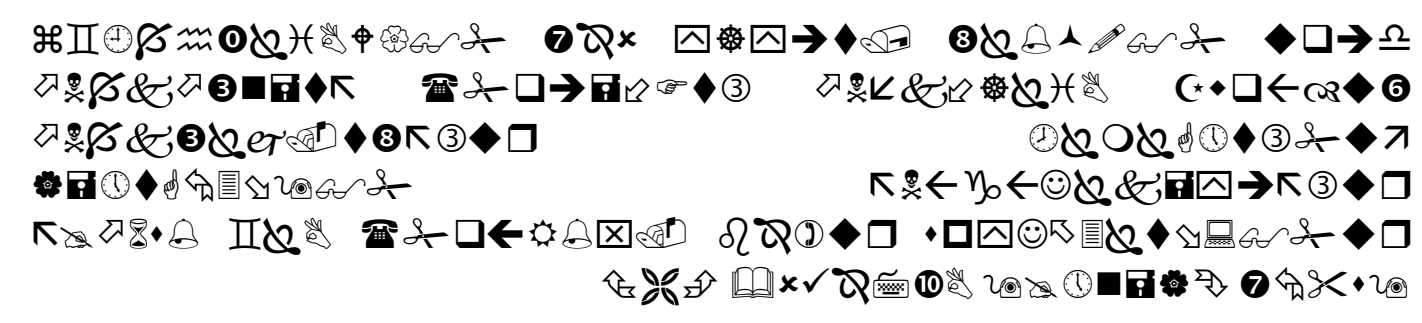

Artinya: Dia-lah yang mengutus kepada kaum yang buta huruf seorang Rasul di antara mereka, yang membacakan ayat-ayat-Nya kepada mereka, mensucikan mereka, dan mengajarkan mereka Kitab dan Hikmah. Dan sesungguhnya mereka sebelumnya benar-benar dalam kesesatan yang nyata.

Perhatikan ketiga ayat tersebut, semua bermula dari tahap tilawah, tazkiyah, lalu ta'lim. Bukankah sebelum kitab dan hikmah itu diajarkan, didahului dengan penyucian dhahir dan bathin, terutama pembersihan ruhani. Bersihkanlah ruhani, lakukanlah riyadhah atau oleh ruhani, maka ilmu dan hikmah akan mudah masuk ke dalam dada. Beruntunglah siapa yang telah dikarunia hikmah, 
kearifan, kebijaksanaan, atau wisdom. Sebagaimana termaktub dalam Al-Qur'an surat Al-Baqarah ayat 269.

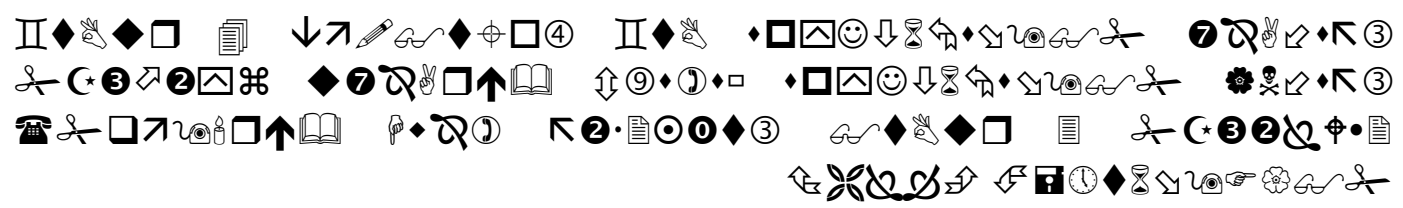

Artinya: Allah menganugerahkan hikmah kepada siapa yang dikehendaki-Nya. Dan barangsiapa yang dianugerahi hikmah, ia benar-benar telah dianugerahi karunia yang banyak. Dan hanya ulul albablah yang dapat mengambil pelajaran (dari firman Allah)."

Tazkiyah itu menurut penulis perlu didahului dengan thaharah. Tazkiyah dan thaharah arti bahasanya sama, yaitu bersuci, tetapi hakikatnya berbeda. Thaharah lebih mengarah pada penyucian jazmani dari najis dan kotoran jazmani sedangkan tazkiyah adalah penyujian ruhani dari najis dan kotoran ruhani. Thaharah perlu dilakuan dengan baik dan benar sebagai bekal untuk melakukan tazkiyah. Masalah thaharah tidak akan dibahas dalam tulisan ini.

\section{F. Keunggulan Hati atas Otak}

Dalam tubuh manusia, kecerdasan yang sebenarnya bukanlah kecerdasan otak atau alat persepsi lahiriyah. Ada kecerdasan yang lebih tinggi yang dapat menangkap pesan-pesan yang sangat abstrak, sekalipun berada di lapisan langit tertinggi atau lapisan bumi terdalam. Otak tidak lain hanyalah sebagai media dari kecerdasan yang satu ini. Dialah kecerdasan hati (qalb). Kecerdasaan ini jarang diberdayakan oleh manusia dan keberadaannya banyak yang tidak mempercayainya atau meragukannya. Bahkan, orang yang menjalankan metode kecerdasan hati dianggap sebagai tidak rasional (Auliya, 2005:xii-xiii).

Kehebatan hati dalam menangkap ilmu melebihi kehebatan otak. Hati mempunyai intuisi-intuisi bathiniyah yang sangat hebat. Al-Qur'an mengisyaratkan bahwa dalam hati (qalb) ada 'aql, fuad (jamak: afidah), lubb (jamak: albab), shadr, bal, dzihn, dan syaghaf. Secara sederhana, 'aql adalah daya yang dapat menangkap, mempersepsi, dan memahami. Fuad adalah daya tertinggi, sangat cerdas, jujur, berpikir universal, dan dapat melihat cahayacahaya ghaib. Fuad dapat melahirkan ma'rifat dan mukasyafah. Lubb adalah daya yang berpikir murni, sangat cerdas, dan substansial. Shadr adalah daya penerbit kepasrahan. Bal adalah daya penyangga. Dzihn adalah daya penyimpan dan pengingat. Syaghafadalah daya penerbit dan penghampar cinta (Auliya, 2005:xvxvi).

Dengan intuisi-intuisi seperti itu, maka hati dapat mengetahui, memahami pelajaran dan akibat-akibat baik, dapat mengingat Allah, dapat merenungi ayat-ayat al-qur'an, dapat melihat Allah, dan dapat berkehendak. Bahkan secara spriritual, hatilah yang menjadi pusat penilaian amal dan pusat manusia merasakan kehadiran Allah. 
Hati dapat menjadi stasiun penerima wahyu, ilham, dan ilmu ladunni. Di dalam hatilah tempat Allah "bersemayam". Dalam suatu hadits yang diriwayatkan oleh Ibnu Umar katanya: Pernah ditanyakan kepada Rasulullah saw.: Ya Rasulullah, di manakah Allah? Di langit atau di bumi? Maka Rasulullah menjawab, "Di dalam hati hamba-hamba-Nya yang beriman" (Al-Ghazali, 2005:6566).

Dalam Al-Qur'an surat Al-Anbiya' ayat 7 disebutkan.

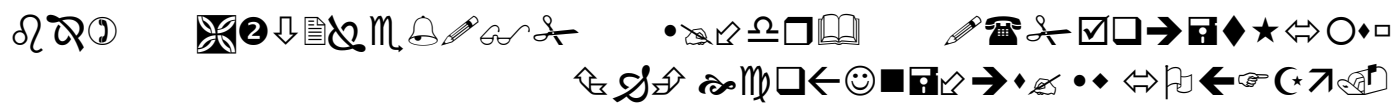

Artinya: .., maka tanyakankah kepada ahli dzikr, jika kamu tiada mengetahui.

Perhatikan, dalam ayat tersebut disebutkan kata ahli dzikir, bukan ahli pikir. Pembaca dapat merenungkannya dengan mendalam. Itulah yang diistilahkan Ebit G. Ade dengan "rumput yang bergoyang". Orang-orang yang selalu bergerak hatinya, bahkan kadang juga ikut bergerakjasmaninya.

Kita mungkin sudah pernah membaca QS Al-Kahfi yang bercerita tentang nabi Musa yang berguru kepada nabi Khidir. Tidakkah kita menemui dan memahami betapa rasio atau pikiran tidak dapat melihat hakikat. Bagaimana nabi Musa dengan rasio yang dimiliki selalu memprotes nabi Khidir mengenai tindakannya yang terlihat salah. Ternyata rasio atau otak hanya mampu melihat pada level permukaan, tetapi hati dapat menembus sampai inti.

Otak hanya dapat berpikir secara rasional, sistematis, dan logis. Sedangkan hati, selain dapat melakukan aktivitas 'aqala (berpikir rasional, sistematis, dan logis), juga melakukan aktivitas yang lain. Al-qur'an banyak menyebutkan aktivitas yang dapat dilakukan hati. Aktivitas tersebut antara lain dabbara (merenung), faqiha (mengerti), fahima (memahami), 'aqala (bernalar), nazhara (melihat), sama'a (mendengar), dzakara (mengingat), fakkara (berpikir), 'alima (mengetahui), dan ittaqa (takut atau menghindar). Aktivitas tersebut merupakan aktivitas mental dan bersifat ruhani.

Otak dan hati (qalb) keduanya mampu menangkap objek-objek nonfisik, tetapi menggunakan pendekatan yang berbeda. Otak menggunakan pendekatan bahtsi (diskursif) sedangkan hati menggunakan pendekatan dzauqi (ekspreriensial). Dalam pendekatan bahtsi, objek-objek nonfisik diketahui melalui penalaran logis menggunakan silogisme. Dengan demikian, objek-objek otak diketahui secara tidak langsung melalui proses pengambilan kesimpulan dari yang tidak diketahui menuju yang tidak diketahui. Pendekatan ini dapat juga disebut pendekatan inferensial.

Hati menggunakan pendekatan dzauqi, intuitif, atau presensial karena objek-objeknya hadir dalam jiwa seseorang, dan karena itu ilmu seperti ini dapat disebut ilmu hudhuri (knowledge by presence). Karena objek-objeknya hadir dalam jiwa, maka manusia dapat mengalami dan merasakannya, dan dari sinilah istilah dzauqi (rasa) muncul. Selain itu objek-objek dapat diketahui secara langsung, karena tidak ada yang memisahkan antara yang subjek dan objek, antara yang 
mengetahui dan yang diketahui. Inilah kelebihan hati atas otak (Kartanegara, 2005:221-222).

\section{G. Kesimpulan}

Penciptaan manusia dilakukan oleh Allah SWT dengan sangat sempurna. Manusia dibekali dengan potensi indera dhahir (jasmani) sekaligus indera bathin (ruhani). Indera dhahir dalam Al-Qur'an diwakili dengan penyebutan pendengaran $\left(\operatorname{sam}^{\prime} a\right)$ dan penglihatan (abshar). Indera bathin dalam Al-Qur'an diwakili dengan penyebutan hati (af'idah). Bekal indera dhahir dan bathin diberikan oleh Allah SWT agar manusia dapat bersyukur. Sebagaimana firman Allah SWT dalam Al-Qur'an surat An-Nahl ayat 78

Artinya: Dan Allah mengeluarkan kamu dari perut ibumu dalam keadaan tidak mengetahui sesuatupun, dan Dia memberi kamu pendengaran, penglihatan dan hati, agar kamu bersyukur.

Bersyukur dapat juga bermakna memelihara dan memanfaatkan indera tersebut dengan baik terutama untuk beribadah. Meskipun demikian, Allah SWT telah menegaskan bahwa sedikit sekali yang mampu mensyukuri nikmat pendengaran $\left(s^{\prime} m^{\prime} a\right)$, penglihatan (abshar), dan hati (af'idah). Perhatikan firman Allah SWT berikut.

1. QS Al-Mu'minuun ayat 78

Artinya: Dan Dialah yang telah menciptakan bagi kamu sekalian, pendengaran, penglihatan dan hati. Amat sedikitlah kamu bersyukur.

2. QS As-Sajdah ayat 9

Artinya: Kemudian Dia menyempurnakan dan meniupkan ke dalamnya roh (ciptaan)Nya dan Dia menjadikan bagi kamu pendengaran, penglihatan dan hati; (tetapi) kamu sedikit sekali bersyukur.

3. QS Al-Mulk ayat 23

Artinya: Katakanlah: "Dia-lah Yang menciptakan kamu dan menjadikan bagi kamu pendengaran, penglihatan dan hati". (Tetapi) amat sedikit kamu bersyukur.

Marilah kita manfaatkan indera dhahir (aql) dan indera bathin (qalb) dengan baik termasuk untuk mempelajari matematika sebagai wujud rasa syukur kepada Allah SWT.

\section{H. Daftar Rujukan}

Agustian, Ary Ginanjar. 2005. Rahasia Sukses Membangun Kecerdasan Emosi dan Spiritual ESQ Berdasarkan 6 Rukun Iman dan 5 Rukun Islam. Jakarta: Penerbit Arga

Al-Ghazali, Imam. 2003. Ihya' Ulumiddin, Jilid 1. Diterjemahkan oleh H.M. Zuhri. Semarang: CV Asy Syifa'

Al-Ghazali. 2005. Keajaiban-keajaiban Hati. Diterjemahkan oleh Muhammad AlBaqir. Bandung: Karisma

Al-Zarnuji. 1996. Etika Belajar bagi Penuntut Ilmu. Terjemah Ta'lim al-Muta'allim Thariq at-Ta'allum oleh A. Ma'ruf Asrori. Surabaya: Al-Miftah 
Auliya, M. Yaniyullah Delta. 2005. Melejitkan Kecerdasan Hati \& Otak: Menurut Petunjuk Alquran dan Neurologi. Jakarta: PT RajaGrafindo Persada

Bahresi, Hussein. Tanpa tahun. Al-Jami'ush Shahih: Hadits Shahih Bukhari-Muslim. Surabaya: CV. Karya Utama

Bell, Frederick H.. 1978. Teaching Learning Mathematics: In Secondary Schools. Iowa: Wm. C. Brown Company.

Dahar, R.W.. 1988. Teori-teori Belajar. Jakarta: P2LPTK

Depag RI. 1989. Al-Qur'an dan Terjemahannya. Surabaya: CV. Jaya Sakti.

Ghazali, Imam. 2004. Ringkasan Ihya' Ulumuddin. Diterjemahkan oleh Labib Mz. Surabaya: Himmah Jaya

Hiebert, James. 1986. Conceptual and Procedural Knowledge: The Case of Mathematics. New Jersey: Lawrence Erlbaum Associates, Publisher.

Hudojo, Herman. 1979. Pengembangan Kurikulum Matematika E Pelaksanaannya di Depan Kelas. Surabaya: Usaha Nasional.

Kartanegara, Mulyadhi. 2005. Integrasi Ilmu: Sebuah Rekonstruksi Holistik. Bandung: Arazi dan UIN Jakarta Press

Kennedy, L.M. dan Tipps, Steve. 1994. Guiding Children's Learning of Mathematics, Seventh Edition. California: Wadsworth Publishing Company.

Majalah INOVASI. 2005. Kontroversi Islamisasi Sains. Edisi 22 Halaman 13-20.

Mudhary, Bahauddin. 2001. Dialog Masalah Ketuhanan Yesus. Surabaya: Pustaka Da'i

Nasoetion, Andi H.. 1980. Landasan Matematika. Jakarta: PT Bhratara Karya Aksara

Skemp, Richard R.. 1987. The Psychology of Learning Mathematics. New Jersey: Lawrence Earlbaum Associates.

Soedjadi, R. 2001. Pemanfaatan Realitas dan Lingkungan dalam Pembelajaran Matematika. Makalah Disampaikan dalam Seminar Nasional "Realistic Mathematics Education (RME)“ di UNESA, tanggal 24 Pebruari.

Van de Walle, John A.. 1990. Elementary School Mathematics: Teaching Developmentally. New York: Longman 